\section{Return of CUltural PROPERTy... SuMMARIES}

The protracted negotiations concerning the return of medieval manuscripts to Iceland from Danish collections is the classic restitution case in Scandinavia. The case is dealt with in three contributions mirroring both the Icelandic and Danish views on the controversy. Vesteinn Ólason in his paper 'The homecoming of the manuscripts in a scholarly and ideological perspective' gives a brief overview of the number of manuscripts, their history and the considerations that finally settled the issue. The manuscripts dating from the period 1200-1500 are the oldest written sources of Norse language and literature. As early as the 17 th century they began to attract the attention and curiosity of scholars who were studying the development and differentiation of old Norse into the various Scandinavian languages, medieval Scandinavian history and literary traditions. The manuscripts were assembled by ardent collectors and taken to Denmark and Sweden. The learned Icelandic scholar Arní Magnússon (1663-1770) was the most famous collector. He became professor at Copenhagen University in 1701 and subsequently spent a decade doing fieldwork in Iceland carrying out the task of preparing a new land tax register. At the same time he systematically collected old manuscripts in order to save the invaluable historical, linguistic and literary source material they represented. The resulting Arnamagnaean Collection was bequeathed to Copenhagen university on his death. During the gradual process of liberation from Denmark leading finally in 1944 to the founding of the Republic of Iceland, demands for the restitution of this cultural heritage were repeatedly voiced. The paper deals specifically with the last phase of restitution in the period 1971-1997. Two institutes had already been established for the scientific work on the documents, one in Copenhagen (Arnamagnæanska Institut in 1957) and one in Reykjavík (Handritastofnun Íslands in 1962, which ten years later was renamed Stofnun Árna Magnússonar á Íslan- di), both offering highly qualified research facilities. The idea was to split the collection between the two institutes which had to guarantee full mutual access to all documents. Sharing was the basic principle.

Birgitte Kjer in 'The manuscript issue - from a Danish point of view' recounts in detail the gradual changes over time in scholarly and public opinion in face of Icelandic demands. The legal aspect was strongly asserted in the beginning: the collection was not stolen but had been rightfully acquired and donated to Copenhagen University and thus to the Danish nation. Step by step, however, the attitude changed in the commissions appointed to handle the requests. It was influenced, for example, by the simultaneous negotiations with Germany on a corresponding issue (dealt with in the paper by Inge Adriansen) and by ongoing changes on the domestic political scene. A definite reversal occurred in the 1960s with the shift in political power. Looking back on the process in 2001 it can be stated that the spirit of sharing and reciprocity in the final agreement has undoubtedly come to be the most important cultural link between the two countries.

Anna Torborg Torgrimsdóttir in 'The return of Icelandic objects in 1930' looks at another category, Icelandic objects in Danish museums. When Iceland was granted self-government in 1918 demands which had first been made in 1907, for the transfer of governmental archives on Icelandic affairs were renewed. The Danes responded favourably and as a consequence in 1924 the return of Icelandic objects in Danish museums was also requested. The museum directors were refractory putting forward legal objections. However, in order to contribute to the celebration of the millenary of the Icelandic 'Alting' in 1930, the politicians circumvented the legal problem by offering as a gift a selection of objects from the debated list for restitution. The point of using the idea of a gift being that the donor was free to decide arbitrarily what would be returned. Such restitutions could not be used as a precedent in the event of similar requests.

Inge Adriansen in 'Return of cultural material be- 
tween Denmark and Germany' relates the problems of the location of historical monuments and cultural objects in a contested geographical area, where national borders have repeatedly moved back and forth. In the Danish/German borderland, Schleswig, with a German-speaking population in the southern part and a Danish-speaking one in the north, wars were waged in 1848-50 and in 1864 . The 1864 peace treaty included a clause on cultural heritage. The town of Flensburg was recognized as being on Prussian ground and the return of the museum collections, which had been evacuated northwards, was requested. The Danes refused, and the return was effected only when the Prussian government offered to pay a considerable sum of money. After WW1 Schleswig was divided according to the outcome of a referendum in the borderland. As it was believed that Flensburg would become part of Denmark, the return was requested of the Flensburg collection, this time evacuated to Kiel, as well as the Isted Lion, a monument erected in the Flensburg churchyard to celebrate a Danish victory at Isted in 1850 but removed by the Germans. However Flensburg remained German. The situation was replicated after WW2. As the result of a quick Danish intervention initiated by a Danish reporter in Berlin who had discovered the Isted Lion there, General Eisenhower allowed it to be transported to Copenhagen in 1945 . The monument has been temporarily put on show, but consensus concerning its final location has not yet been reached. The paper ends by drawing attention to the wicked destruction and defacement of German memorials erected in Denmark during the period of occupation 1940-45 but also to the peaceful relations between German and Danish museums in the borderland that has resulted in the reciprocal depositing of artefacts to their rightful locations. Finally the question is asked: What is an inalienable cultural heritage?

Tarmo Jomppanen, director of the recently established Sami museum in northern Finland, in 'The Sami museum at Inari and the Sami heritage in Finland' discusses the responsibility the museum has to serve as the unique centre in the country for the cultural memory of a minority population. Sami artefacts and documentation are dispersed in various museums not only in Finland but all over Europe. The need to map and list this scattered heritage is a primary concern and should preferably be done in cooperation with Sami museums in Norway and Sweden before entering into the problems of restitution.

Emil Rosing's contribution, 'Return of museum objects from Denmark to Greenland', deals with the efforts to restore to Greenland those parts of its material heritage lodged in Danish museums. The successful negotiations with the National Museum in Copenhagen are recounted. These negotiations have also led to shared responsibility for the registration and safeguarding of ancient monuments in Greenland.

Arne Thorsteinsson describes the considerable collecting of artefacts in the Faroe Islands for Danish museums from 1820 and onwards. Among the collectors particular mention is made of: Daniel Bruun, the pioneer of the study of Norse culture on the North Atlantic islands, who collected for the 1900 World Exhibition in Paris; Doctor R.K. Rasmussen collecting for Folkemuseet in the 1930s and Bjarne Stoklund bringing together furniture and equipment for the Faroe farmyard in the Copenhagen open air museum, Frilandsmuseet. A museum was founded on the Faroes in 1898 and from the early 20th century requests were voiced for the return of objects to the islands. Especially coveted was the medieval inventory from Kirkjubø Cathedral. Eventually requests from the Faroe local assembly to the Danish government were successful. The title of the paper 'Back to the Faroes' refers to the ceremony in 2002 when some hundreds of objects from the Danish National Museum were handed over to the Faroe National Museum, among them the inventory from Kirkjubø. The restitution was achieved after a meticulous process involving exhibiting and documenting of the collection in Copenhagen.

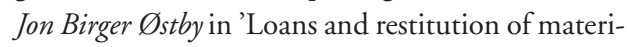
al in Norwegian Museum collections' presents the ge- 
60 neral principles to be applied in Norwegian museums regarding questions of restitution, loan and deposition which are usually raised by regional and local museums respecting objects in national collections. A report was presented in 2000 by a committee consisting of ten representatives of various categories of museums. The report covers eleven areas ranging from the purpose of museum collections and the ownership and management of collections, to general criteria to be applied to issues of loan and restitution, and recommendations concerning the decision-making process. The paper focuses on the question of general criteria and the recommendations for action made by the committee. The decisions regarding the return of Samí artefacts to museums and centres in 'Samiland' in northernmost Norway are specifically discussed.

Finally Monika Minnhagen-Alvsten in 'Reflections on the return of cultural property to its place of origin' gives various concrete examples of how demands for the return of cultural property have been handled by national museums in Sweden. Referring to Hugo Grotius, founder of international law in the early 17 th century, she underlines the fact that looting in time of war was both acceptable and legal before nationalist ideologies emerged in the late 18th and early 19th centuries. In 1989 the UN General Assembly passed a resolution on the restitution of cultural property. Sweden abstained from voting, stating that such decision must be taken case by case. In the paper a variety of cases are accounted for, five of which are cited here.

The Ethnographic Museum's return in 1994 of a totem pole acquired in 1929 from a Haisla village in British Columbia was defined as a gift of the Swedish government. It was based on an agreement that a replica could be kept in Stockholm and that a museum building which could guarantee its preservation in its place of origin would be erected to house the gift.

The Nordic Museum, according to its founder Artur Hazelius, was intended to present material culture from the Scandinavian countries. Initially a considerable Norwegian collection was acquired. When the uni- on between the two countries was dissolved in 1905 the collection consisted of 16000 objects. Proposals have since been made regarding a return of the objects to Norway. In 1982 after an argument about who should be the proper receiver they were finally returned to Norsk Folkemuseum in Oslo as a long-term deposition.

When towards the end of WW2 Estonians fled to Sweden many church treasures were taken for safekeeping to the Historical Museum in Stockholm. As they were not formally acquired but only deposited temporarily it has been easy to return them to the churches which were able to use them once again for their original purposes after the liberation of the country from the Soviet Union.

In the city of Linköping a treasure trove of 6 kilo silver was unearthed by a ploughman in 1676 . According to the law the state had the right of ownership provided that the finder was paid the value of the weight of the metal. In Linköping Cathedral a museum has recently opened and in the regional newspaper a plea was made for the return of the objects which had been used in Christian rituals. The National Board of Antiquities refused as the treasure was historically unique, but had to allow them to be put temporarily on show for the inauguration of the museum.

In Skåne the skeleton of a woman was discovered and excavated in 1939. 'The Barum woman' is the oldest known female skeleton, dating back to the Old Stone Age (8 $000 \mathrm{BC})$. It is one of the most treasured exhibits in the Historical Museum in Stockholm, but attempts have been made to have it returned to a regional museum in Skåne. But what would happen if it was argued that in fact it ought to be on show in the small village of Barum?

The last mentioned cases reflect the increasing interest on the part of the tourist industry in exploiting cultural heritage as an attraction. It has become a complex problem for institutions with the responsibility of safeguarding the artefacts to withstand the often politically voiced pressures in similar cases and to find viable compromises. 